\title{
Kompleks Polymer dari Ion Logam Ni(II) dengan Ligan 2,4,5-triphenyl-1H-imidazol Sebagai Material Penyimpan Hidrogen
}

\author{
Fahimah Martak, Fawait Afnani, Agus Wahyudi \\ Jurusan Kimia, Institut Teknologi Sepuluh Nopember, Surabaya, Indonesia \\ Email :fahimahm@chem.its.ac.id
}

\begin{abstract}
Abstrak--Kompleks polimer $\quad\left\{\left[\mathrm{Ni}(\mathrm{NCS})_{2}(2,4,5 \text {-triphenyl-1H-imidazol })_{2}\left(\mathrm{H}_{2} \mathrm{O}\right)_{2}\right] \cdot \mathrm{DMF}\right\}_{\mathrm{n}} \quad$ telah berhasil disintesis dengan metoda solvotermal. Hasil sintesis diperoleh padatan hijau kekuningan. Komposisi kimia senyawa hasil sintesis ditentukan dengan spektroskopi serapan atom dan analisis unsur $(\mathrm{Ni}=7,28 \% ; \mathrm{C}=72,23 \% ; \mathrm{H}=5,87 \% ; \mathrm{N}=11,97 \%$ and $\mathrm{S}=8,03 \%)$. Terdapat vibrasi Ni$\mathrm{N}_{\text {(imidazole) }}$ pada bilangan gelombang $378 \mathrm{~cm}^{-1}$ ditunjukkan spektrum infra merah. Hasil Analisis termal kompleks polimer diperoleh tiga tahap dekomposisi pada temperatur $80-320{ }^{\circ} \mathrm{C}$. Ukuran partikel kompleks polimer ini antara 7-12 $\mu \mathrm{m}$ dan kapasitas adsorbsi hidrogen sebesar 2,048\% berat. Ini menunjukkan bahwa kompleks polimer ini berpotensi sebagai material penyimpan hidrogen.
\end{abstract}

Kata kunci: adsorbsi hidrogen, ion logam $\mathrm{Ni}^{2+}$, kompleks polimer, 2,4,5-triphenyl-1H-imidazoles ligand, ligan thiocyanate, solvotermal, material penyimpan hidrogen.

\section{Pendahuluan}

Krisis dalam bidang energi dan ekonomi mengakibatkan harga crude oil semakin meningkat. Salah satu upaya kebijakan Menteri Energi dan Sumber Daya Mineral menurunkan ketergantungan ini adalah upaya energi terbarukan (alternative energy). Diantara energi alternatif, hidrogen adalah pilihan tepat sebagai bakar atau penyimpan energi karena energi yang dapat diperbarui dan bebas emisi [Mazloomi and Gomez, C., 2012]. Hidrogen mampu menghasilkan energi lebih tinggi sebesar $34.0 \mathrm{Kcal} / \mathrm{g}$ dibandingkan nilai petroleum yang menghasilkan energi dari 8.4 to $10.3 \mathrm{Kcal} / \mathrm{g}$ sehingga dapat digunakan sebagai bahan bakar alternatif sebagai pengganti bahan bakar fossil [Jain, P., 2009].

Kerapatan hidrogen yang rendah yang membuat hidrogen harus disimpan dengan menggunakan material penyimpan hidrogen [Hirscher, 2009]. Tentusaja, gas hidrogen harus disimpan sehingga kandungan energi sebesar 34,0 Kcal/g dapat digunakan. Salah satu material yang dapat digunakan sebagai penyimpan hidrogen adalah material berpori. Salah satu upaya untuk meningkatkan kerapatan hidrogen dalam dinding pori dalam jumlah besar pada tekanan dan temperatur rendah mendekati lingkungan. Material yang termasuk dalam kategori ini adalah zeolit, karbon nanostruktur (seperti karbon nanotube, grafit nanofiber, karbon nanohorn, karbon aktif, klathrat hidrat, logam hidrida dan kompleks polimer (metal-organic framework) atau polimer organik mikropori [Thomas, K. M., 2007]. Material yang termasuk dalam kelompok kompleks polimer menunjukkan absorbsi $\mathrm{H}_{2}$ dalam jumlah besar [Dinca, M., dkk, 2006]. Selain itu, kompleks polimer memiliki struktur tiga dimensi yang dapat membentuk geometri pori yang dapat digunakan sebagai adsorbsidesorbsi hidrogen.

Kompleks polimer dapat dirancang melalui koordinasi ion logam dan ligan multidentate yang disebut sebagai ligan jembatan (bridging ligand), dimana ligand anion yang mengandung atom nitrogen, oksigen and sulfur biasa digunakan sebagai ligan jembatan dalam framework melalui ikatan koordinasi [Noro, dkk., 2009]. Ligan imidazol dapat sebagai ligan jembatan karena mempunyai dua atom $\mathrm{N}$ pada cincin imidazol sehingga dapat membentuk kompleks polimer. Ion logam Ni(II) sebagai ion logam pusat dalam framework berperan penting dalam interaksi dengan $\mathrm{H}_{2}$ [Hoang, T., dkk, 2009]. Ion logam $\mathrm{Ni}$ (II) digunakan sebagai ion logam dalam komplex polimer memiliki interaksi kuat sehingga dapat meningkatkan adsorbsi hidrogen seperti yang telah dilaporkan [Karayannis, dkk,1982]. Struktur oktahedral kompleks yang mengandung ligand 2,4,5triphenyl-1H-imidazole dan ion logam Ni(II) memiliki efek sterik yang besar [Karayannis, N.M., 1982]. Oleh 
karena itu, penambahan ligand -NCS- diperlukan untuk menurunkan efekt sterik pada kompleks polimer [Nobakht, V., dkk, 2014].

Pada artikel ini, dipelajari kompleks polimer $\left\{\left[\mathrm{Ni}(\mathrm{NCS})_{2}(\mathrm{~L})_{2}\left(\mathrm{H}_{2} \mathrm{O}\right)_{2}\right] \cdot \mathrm{DMF}\right\} \mathrm{n} \quad(\mathrm{L}=2,4,5$-triphenyl$1 \mathrm{H}$-imidazole) yang telah disintesis dengan metode solvotermal pada temperatur $120^{\circ} \mathrm{C}$ selama 2 hari. Pelarut yang digunakan adalah dimetil formamida (DMF), pelarut ini dapat melarutkan rantai polimer yang sulit larut sehingga dapat digunakan untuk rekristalisasi [Wild, A., dkk, 2013]. Penambahan cincin aromatik pada turunan imidazol dapat meningkatkan interaksi dengan molekul hidrogen sehingga meningkatkan kapasitas adsorpsinya. Telah dilaporkan Myunghyun, dkk. (2012), kompleks polimer yang memiliki cincin aromatik dapat meningkat kemampuan adsorbsi $\mathrm{H}_{2}$. Kompleks polimer yang dihasilkan dilakukan pengukuran adsorbsi $\mathrm{H}_{2}$ untuk mengetahui kapasitas penyimpan hidrogen.

\section{Metode Penelitian}

\subsection{Material}

Bahan yang digunakan dalam studi ini adalah $\mathrm{NiCl}_{2} \cdot 6 \mathrm{H} 2 \mathrm{O}$ (Merck), 2,4,5-triphenyl-1H-imidazol (Sigma-Aldrich), NH4NCS (Merck), DMF (Merck), methanol (Merck), $\mathrm{KBr}$ pellet, gas nitrogen dan hidrogen.

\subsection{Peralatan}

Peralatan yang digunakan dalam studi ini adalah labu ukur, beker gelas, corong Buchner, neraca analitik, oven listrik, hotplate, magnetic stirrer, peralatan reflux, rotary evaporator R-210 (Buchi), analisis unsur CHNS (Thermo Finnigan EA 1112), Atomic Absorption Spectroscopy (AAS), UV-Vis (Thermo Electron Sci. Inst UV-VIS Spectrophotometer 335908P-000), FTIR (8400S Shimadzu), Thermogravimetry Analyzer (TGAMETTLER TOLEDO), Scanning Electron Microscope (SEM-Zeiss, EVO MA10) dan peralatan isotherms adsorpsi $\mathrm{H} 2$.

\subsection{Sintesis Kompleks Polimer}

Kompleks polimer disintesis dengan perbandingan mol 1:4:2 $\mathrm{NiCl}_{2} \cdot 6 \mathrm{H}_{2} \mathrm{O} \quad(0,12 \mathrm{~g}, \quad 0,5 \mathrm{mmol}), \quad 2,4,5-$ triphenyl-1H-imidazole $(0,60 \mathrm{~g}, 2 \mathrm{mmol})$ dan $\mathrm{NH}_{4} \mathrm{NCS}$ $(0,08 \mathrm{~g}, 1 \mathrm{mmol})$ dilarutkan in DMF $(15 \mathrm{~mL})$ dan direluks pada $70{ }^{\circ} \mathrm{C}$ selama 3 jam. Kemudian larutan kompleks dipanaskan dalam oven pada $120{ }^{\circ} \mathrm{C}$ selama 2 hari. Larutan tersebut dipanaskan selama 3 jam pada temperatur $100{ }^{\circ} \mathrm{C}$ under vacuum to obtain kristal kuning kehijauan. Kristal yang dihasilkan disaring, ditempatkan pada desikator yang mengandung P4O10.
Selanjutnya, kristal yang dihasilkan dilakukan karakterisasi.

\subsection{Spektroscopi UV-Vis}

Larutan $\mathrm{NiCl}_{2} \cdot 6 \mathrm{H}_{2} \mathrm{O}$, larutan $2,4,5-$ triphenyl- $1 \mathrm{H}-$ imidazole, dan kristal compleks polimer $\left\{\left[\mathrm{Ni}(\mathrm{NCS})_{2}(2,4,5\right.\right.$-triphenyl-1H-

imidazole $\left.\left.)_{2}\left(\mathrm{H}_{2} \mathrm{O}\right)_{2}\right] \cdot \mathrm{DMF}\right\} \mathrm{n}$ yang telah dilarutkan dalam DMF 0.01 M. Ketiga larutan ditentukan absorbansinya pada panjang gelombang $200-700 \mathrm{~nm}$.

\subsection{Analisis unsur dengan Spectrometer Serapan Atom (AAS) dan CHNS analyzer}

Sebanyak 0,14 gram sampel kompleks polimer dalam $10 \mathrm{~mL}$ pelarut dianalisis dengan dengan Spektrometer Serapan Atom (AAS) untuk menentukan kandungan nikel.

Komposisi $\mathrm{C}, \mathrm{H}, \mathrm{N}$ and $\mathrm{S}$ diperoleh dengan elemental analyzer C, H, N, S. 1,5 mg sampel dimasukkan dalam aluminium foil, sampel tersebut ditambahkan vanadium oxide. Sampel ditempatkan pada cawan holder sebelum dibakar dengan oksigen. Sebelum instrument digunakan, dilakukan standarisasi dengan L-Cistina Standard $\left(\mathrm{C}_{49} \mathrm{H}_{43} \mathrm{NiN}_{7} \mathrm{O}_{3} \mathrm{~S}_{2}(805,85 \mathrm{~g} / \mathrm{mol})\right.$.

\subsection{Spectroskopy FT-IR}

Polikristalin yang telah disintesis ditambahkan dengan Kbr (1:100), kemudian digerus dengan mortar agat sampai homogeny dan terbentuk pellet. Kemudian, pellet dimasukkan dalam holder FT-IR dan di identifikasi pada $\mathrm{v}=4000-375 \mathrm{~cm}^{-1}$

\subsection{Thermal Gravimetry Analyzer (TGA)}

Sampel 12,3 mg dianalisis dengan TGA-Mettler Toledo. Sampel dimasukkan pada holder. Kemudian dikarakterisasi dengan laju temperatur $10 \mathrm{oC} /$ menit dan tekanan gas nitrogen $0-500^{\circ} \mathrm{C}$

\subsection{Scanning Electron Microscopy-Energy Dispersive $X$-Ray (SEM-EDX)}

Sampel $\quad\left\{\left[\mathrm{Ni}(\mathrm{NCS})_{2}(2,4,5\right.\right.$-triphenyl-1Himidazole $\left.\left.)_{2}\left(\mathrm{H}_{2} \mathrm{O}\right)_{2}\right] \cdot \mathrm{DMF}\right\} \mathrm{n}$ dipreparasi dengan pengambilan sedikit sampel pada permukaan sampel holderyang telah diberi karbon. Kemudian sampel dilapisi dengan palladium. Selebihnya sampel dimasukkan pada sampel chamber dalam SEM dan dilakukan scanning untuk mengetahui performa morfologi Kristal

\subsection{Kapasitas Adsorpsi Hidrogen}

Pengukuran adsorbs gas hydrogen dilakukan dengan menggunakan metode gravimetric. Sampel dimasukkan dalam wadah sampel. Aliran gas hidrogen diatur $20 \mathrm{~mL} / \mathrm{menit}$ secara konstan. Kemudian tabung furnish 
dihubungkan pada pompa vakum yang telah dinyalakan dan diatur pada temperatur pada $350^{\circ} \mathrm{C}$ selama 3 jam untuk menghilangkan gas. Berat sampel dianalisis sampai mencapai berat konstan, kenaikan temperatur pada $350^{\circ} \mathrm{C}$ menggunakan persamaan 3.1. Berat sampel dicatat sebagai berat awal atau berat sebelum adsorbsi hidrogen $\left(\mathrm{m}_{\mathrm{o}}\right)$. Setelah tabung furnish dimatikan dan dibiarkan hingga mencapai terperatur kamar (28 oC). setelah mencapai temperatur kamar, silinder gas $\mathrm{H}_{2}$ dihubungkan oleh reactor dan dialiri secara perlahan. Perubahan berat sampel diamati setiap 2 menit sampai mencapai berat konstan. Berat ini dicatat sebagai berat akhir atau berat setelah adsorbs $\mathrm{H}_{2}(\mathrm{~mL})$. Kapsitas adsorbs $\mathrm{H}_{2}$ dihitung menggunakan persamaan dibawah ini :

$$
\% H_{2}=\frac{\left(m_{t}-m_{0}\right)}{m_{0}} \times 100 \quad 3.1
$$

Dimana \% H2 adalah presentase berat gas hidrogen yang teradsobsi, $\mathrm{mt}$ adalah berat sampel setelah proses adsorbs gas $\mathrm{H} 2$, mo adalah berat awal sampel sebelum proses adsorbsi gas $\mathrm{H} 2$.

\section{Hasil dan Pembahasan}

\subsection{Synthesiskompleks polimer Ni(II)-tiosianat dengan ligan 2,4,5-trifenil-1H-imidazol}

Berdasarkan penelitian Karayannis et al., (1982) menunjukkan bahwa ligan 2,4,5-triphenyl-1H-imidazole memiliki hambatan sterik yang cukup besar untuk membentuk ikatan kordinasi dengan ion logam Ni(II). Oleh karena itu, perlu ditambahkan penambahan ion NCS- untuk kestabilan kompleks yang terbentuk. Selain itu kompleks tersebut dapat terbentuk struktur oktahedral yang dapat membentuk pori, jadi kompleks ligan NCS- dalam polimer membentuk kerangka pori dengan 2 ligan NCS- dan 2 ligan 2,4,5-trifenil-1Himidazol-1H-imidazol. Kristal kompleks yang dihasilkan ditunjukkan pada Gambar 3.1.

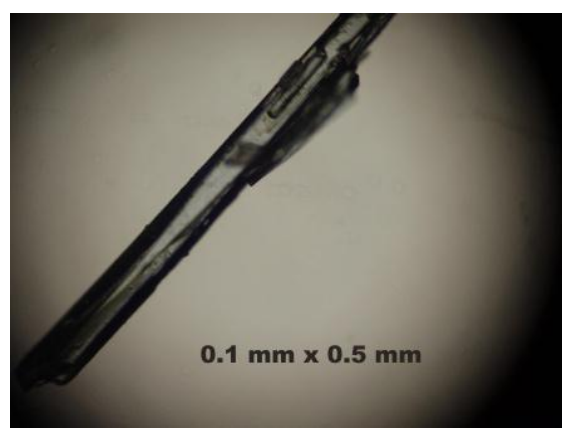

\section{Gambar 3.1 Foto Kristal Kompleks Polimer $\left\{\left[\mathrm{Ni}(\mathrm{NCS})_{2}(2,4,5 \text {-trifenil-1H-imidazol })_{2}\left(\mathrm{H}_{2} \mathrm{O}\right)_{2}\right]\right.$ -DMF $\}_{\mathbf{n}}$}

Sintesis kompleks $\left\{\left[\mathrm{Ni}(\mathrm{NCS})_{2}(2,4,5\right.\right.$-trifenil- $1 \mathrm{H}-$ imidazol $\left.\left.)_{2}\left(\mathrm{H}_{2} \mathrm{O}\right)_{2}\right] \cdot D M F\right\} n$ telah dilakukan dengan menggunakan metode solvotermal. Kristal kompleks yang dihasilkan memiliki rendemen $75 \%$ berat. Kompleks polimer yang terbentuk bersifat higroskopis, tetapi relative stabil pada temperatur ruang dan dapat disimpan dalam desikator. Kompleks polimer tidak larut dalam pelarut methanol, etanol, klorofom dan asetonitril. Kompleks larut dalam pelarut DMF karena senyawa tersebut dapat melarutkan senyawa polar aprotik dan senyawa polar $\left(\mathrm{NH}_{4} \mathrm{SCN}\right.$ dan $\left.\mathrm{NiCl}_{2} \cdot 6 \mathrm{H}_{2} \mathrm{O}\right)$ dan nonpolar (2,4,5-trifenil-1H-imidazol).

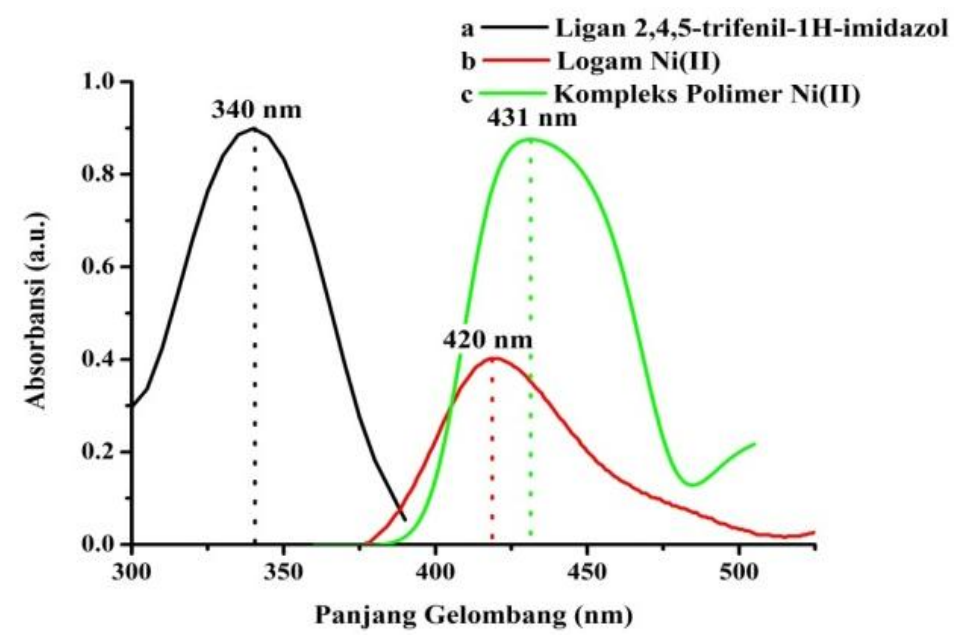

Gambar 3.2 Spektrum UV-Vis: A ligands 2,4,5-trifenil-1H-imidazol (b) Ion Ni(II) and (c) Kompleks Polimer $\left\{\left[\mathrm{Ni}(\mathrm{NCS})_{2}(2,4,5 \text {-trifenil-1H-imidazol })_{2}\left(\mathrm{H}_{2} \mathrm{O}\right)_{2}\right] \cdot \mathrm{DMF}\right\} \mathrm{n}$ 


\subsection{Analisis Kompleks Polimer \\ Spektroskopi UV-Vis}

Analisis spektrofotometer UV-Vis digunakan untuk menentukan pola spectra dari senyawa kompleks. Warna kuning kehijauan dari kompleks polimer $\left\{\left[\mathrm{Ni}(\mathrm{NCS})_{2}(2,4,5 \text {-trifenil-1H-imidazol })_{2}\left(\mathrm{H}_{2} \mathrm{O}\right)_{2}\right] \cdot \mathrm{DMF}\right\} \mathrm{n}$ terbentuk dari transisi elektronik antara perbedaan dua tingkat energi. Analisis spektra senyawa komplek polimer ditunjukkan pada pengukuran pada panjang gelombang 300-600 $\mathrm{nm}$.

Gambar 3.2 menunjukkan bahwa panjang gelombang maksimum dari larutan $\mathrm{NiCl}_{2} \cdot 6 \mathrm{H} 2 \mathrm{O}$ adalah $420 \mathrm{~nm}$ dan larutan 2,4,5-triphenyl-1H-imidazole sebesar $340 \mathrm{~nm}$, sedangkan pada kondisi yang sama larutan kompleks polimer

$\left\{\left[\mathrm{Ni}(\mathrm{NCS})_{2}(2,4,5\right.\right.$-trifenil- $1 \mathrm{H}-$ imidazol $\left.\left.)_{2}\left(\mathrm{H}_{2} \mathrm{O}\right)_{2}\right] \cdot D M F\right\} n$ menyerap sinar tampak pada panjang gelombang $431 \mathrm{~nm}$. Pergeseran panjang gelombang maksimum antara larutan $\mathrm{NiCl}_{2} \cdot 6 \mathrm{H}_{2} \mathrm{O}$, larutan ligan 2,4,5-trifenil-1H-imidazol dan larutan kompleks polimer $\quad\left\{\left[\mathrm{Ni}(\mathrm{NCS})_{2}(2,4,5\right.\right.$-trifenil- $1 \mathrm{H}-$ imidazol $\left.)_{2}\left(\mathrm{H}_{2} \mathrm{O}\right)_{2}\right] \cdot \mathrm{DMF}$;n mengindikasian bahwa telah terbentuk kompleks polimer antara ion Ni(II), NCS-, dan 2,4,5-trifenil-1H-imidazol. Perbedaan panjang gelombang menunjukkan transfer muatan dari logam ke ligan, menghasilkan transisi elektronik dari sebuah elektron pada orbital molekul logam yan lebih dominan. Indikasi transfer muatan dari logam untuk ligan terjadi pada polimer kompleks $\left\{\left[\mathrm{Ni}(\mathrm{NCS})_{2}(2,4,5\right.\right.$-trifenil- $1 \mathrm{H}-$ imidazol $\left.\left.)_{2}\left(\mathrm{H}_{2} \mathrm{O}\right)_{2}\right] \cdot \mathrm{DMF}\right\} \mathrm{n}$ memiliki ligan dengan orbital $\pi$ antibonding.

\section{Analisis kandungan ion logam, unsur $C, H, N$ dan $S$}

Analisis dengan spektroforometri serapan atom (SSA) dan mikroelement analyser digunakan untuk menentukan formula kompleks. Analisa AAS pada studi ini digunakan untuk mengatahui kandungan nikel, sedangkan $\mathrm{C}, \mathrm{H}, \mathrm{N}, \mathrm{S}$ analyser digunakan untuk menentukan karbon, hidrogen, nitrogen dan sulfur pada kompleks polimer. Tabel 3.1 menunjukkan hasil analisis unsur dan perhitungan teoritis formula yang paling sesuai untuk kompleks polimer $\left\{\left[\mathrm{Ni}(\mathrm{NCS})_{2}(2,4,5-\right.\right.$ trifenil-1H-imidazol $\left.\left.)_{2}\left(\mathrm{H}_{2} \mathrm{O}\right)_{2}\right] \cdot \mathrm{DMF}\right\} \mathrm{n}$.

Kandungan nikel pada kompleks polimer memiliki kesesuaian dengan perhitungan teoritis. Sementara perbedaan kandungan $\mathrm{C}, \mathrm{H}, \mathrm{N}$ dan $\mathrm{S}$ antara hasil eksperimen dan perhitungan teoritis karena ketidakmurnian senyawa, namun masih dapat diterima. Ini karena perbedan antara perhitungan eksperimen dan teori dibawah $5 \%$. Data hasil analisis unsur senyawa dan perhitungan teoritis ditunjukkan pada Tabel 3.1.

\section{Analisis Gugus Fungsi}

Pada uji Spektrofotometer FT-IR kompleks polimer $\left\{\left[\mathrm{Ni}(\mathrm{NCS})_{2}(2,4,5 \text {-trifenil-1H-imidazol })_{2}\left(\mathrm{H}_{2} \mathrm{O}\right)_{2}\right] \mathrm{DMF}\right\} \mathrm{n}$ diukur pada nilangan gelombang 4000-375 $\mathrm{cm}^{-1}$. Hasil spektrum digunakan untuk mengindikasikan gugus fungsi senyawa organik ligan pada bilangan gelombang 4000-1400 $\mathrm{cm}^{-1}$. Hasil spektrum digunakan untuk mengindikasikan ikatan logam dengan ligan pada struktur kompleks polimer terjadi pada daerah finger print dibawah $1400 \mathrm{~cm}^{-1}$.

Spektrum dari ligan 2,4,5-trifenil-1H-imidazol menyerap pada bilangan gelombang $1510 \mathrm{~cm}^{-1}$ mengindikasikan vibrasi stretching $\mathrm{C}=\mathrm{N}$, sedangkan pada bilangan gelombang $3434 \mathrm{~cm}^{-1}$ muncul stretching vibrasi dari N-H, dan vibrasi pada 2993, 2470, 1638 $\mathrm{cm}^{-1}$ dimana menunjukkan serapan stretching $\mathrm{C}=\mathrm{C}$ aromatik [Marzouk, A., dkk, 2013]. Bila dibandingkan dengan kompleks polimer ini , vibrasi dari $\mathrm{C}=\mathrm{N}$ dan $\mathrm{N}$ $\mathrm{H}$ dari imidazol muncul pada 1504, $3398 \mathrm{~cm}^{-1}$, dan vibrasi dari $\mathrm{C}=\mathrm{C}$ aromatik muncul di 3037, 2449, 1649 $\mathrm{cm}^{-1}$. Terdapat kesesuaian dengan laporan sebelumnya [Marzouk, A., dkk, 2013]. Spektrum FT-IR kompleks tersebut ditunjukkan pada Gambar 3.3.

Tabel 3.1 Data Kandungan Unsur Kompleks dari Hasil Eksperimen dan Perhitungan Teoritis

\begin{tabular}{|c|c|c|c|c|c|c|}
\hline Rumus Molekul & $\begin{array}{c}\mathrm{Mr} \\
(\mathrm{g} / \mathrm{mol})\end{array}$ & $\% \mathrm{Ni}$ & $\% \mathrm{C}$ & $\% \mathbf{H}$ & $\% \mathrm{~N}$ & $\% \mathrm{~S}$ \\
\hline Sample (eksperimen) & & 7,32 & 72,23 & 5,87 & 11,68 & 8,03 \\
\hline$\left[\mathrm{Ni}(\mathrm{NCS})_{2}(\mathrm{~L})_{2}\left(\mathrm{H}_{2} \mathrm{O}\right)_{2}\right]$ & 732,77 & 8,01 & 75,54 & 4,96 & 11,47 & 8,75 \\
\hline$\left[\mathrm{Ni}(\mathrm{NCS})_{2}(\mathrm{~L})_{2}\left(\mathrm{H}_{2} \mathrm{O}\right)_{2}\right] \cdot \mathrm{DMF}$ & 805,85 & 7,28 & 72,03 & $5, .39$ & 12,17 & 7,95 \\
\hline$\left[\mathrm{Ni}(\mathrm{NCS})_{2}(\mathrm{~L})_{2}\left(\mathrm{H}_{2} \mathrm{O}\right)_{2}\right] \cdot 2 \mathrm{DMF}$ & 878,94 & 6,68 & 71,05 & 5,74 & 12,75 & 7,29 \\
\hline$\left[\mathrm{Ni}(\mathrm{NCS})_{2}(\mathrm{~L})_{2}\left(\mathrm{H}_{2} \mathrm{O}\right)_{2}\right] \cdot 3 \mathrm{DMF}$ & 952,03 & 6,16 & 69,38 & 6,05 & 13,24 & 6,73 \\
\hline
\end{tabular}

\section{$\mathrm{L}=$ 2,4,5-trifenil-1H-imidazol}




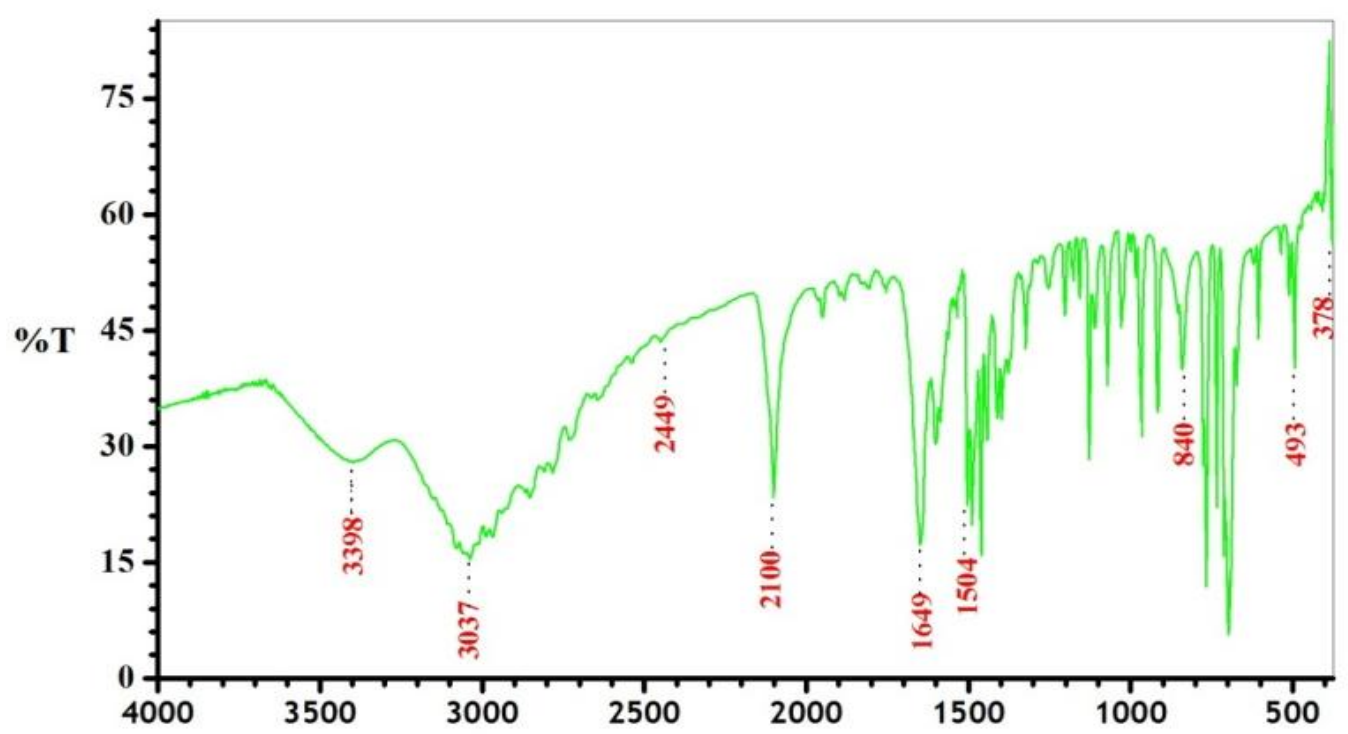

$1 / \mathrm{cm}$

Gambar 3.2 Spektrum FTIR $\left.\left[\mathrm{Ni}(\mathrm{NCS})_{2}(2,4,5 \text {-trifenil-1H-imidazol })_{2}\left(\mathrm{H}_{2} \mathrm{O}\right)_{2}\right] \cdot \mathrm{DMF}\right\}_{\mathrm{n}}$

Gerak vibrasi regangan $\mathrm{C}-\mathrm{N}$ asimetris yang telah diteliti menghasilkan puncak serapan kuat pada 2100 $\mathrm{cm}^{-1}$ ( $\mu$-NCS-bridging) [Bailey, R.A., dkk, 1971] dan vibrasi C-S pada $840 \mathrm{~cm}^{-1}$. Ikatan koordinasi NCS melalui atom $\mathrm{N}$ dengan ion logam $\mathrm{Ni}(\mathrm{II})$ pada bilangan gelombang $493 \mathrm{~cm}^{-1}$ membuktikan keberadaan anion tiosianat yang terikat pada atom terminal N. Hal ini sesuai dengan kisaran vibrasi $\mathrm{C}-\mathrm{N}$ pada bilangan gelombang 2075-2128 $\mathrm{cm}^{-1}$, rentang vibrasi C-S pada $780-851 \mathrm{~cm}^{-1}$ dan vibrasi M-NCS terjadi disekitar $\sim 480$ cm-1 [Clark, R.J.S. 1996]. Ikatan Ni-N (imidazol) bervibrasi di kisaran bilangan gelombang 320-380 cm-1 dan 400-230 $\mathrm{cm}^{-1}$ [Xue, G., dkk., 1994]. Pada spektrum FT-IR, kompleks $\left\{\left[\mathrm{Ni}(\mathrm{NCS})_{2}(2,4,5\right.\right.$-trifenil-1Himidazol $\left.\left.)_{2}\left(\mathrm{H}_{2} \mathrm{O}\right)_{2}\right] \cdot \mathrm{DMF}\right\}_{\mathrm{n}}$ menunjukkan vibrasi Ni$\mathrm{N}$ (imidazol) muncul pada bilangan gelombang $378 \mathrm{~cm}^{-1}$. Pergeseran bilangan gelombang menunjukkan terbentuk kompleks dengan ligan imidazol dan tiosianat [Nakamoto, 1986].

\section{Thermal Gravimetry Analizer (TGA)}

Umumnya, aplikasi material kompleks polimer sebagai penyimpanan hidrogen yang memiliki stabilitas termal cukup tinggi. Pengujian stabilitas termal digunakan untuk menentukan dekomposisi termal padatan [Brown, M.E 2001]. Instrumen TGA dilengkapi timbangan yang berisi sampel dengan berat yang telah ditentukan. Gas pembawa (nitrogen) dialirkan ke sampel dan timbangan, dipantau sebagai fungsi suhu. Stabilitas termal $\left\{\left[\mathrm{Ni}(\mathrm{NCS})_{2}(2,4,5\right.\right.$-trifenil- $1 \mathrm{H}$ imidazol $\left.\left.)_{2}\left(\mathrm{H}_{2} \mathrm{O}\right)_{2}\right] \cdot \mathrm{DMF}\right\} \mathrm{n}$ dengan berat awal $12,3 \mathrm{mg}$ dipanaskan pada suhu $500{ }^{\circ} \mathrm{C}$ dengan peningkatan pemanasan $10{ }^{\circ} \mathrm{C} /$ menit dalam aliran gas nitrogen ditunjukkan pada Gambar 3.4.

Dalam kurva TG-DTA, terdapat tiga puncak eksotermik antara 50-500 ${ }^{\circ} \mathrm{C}$. Tahap pertama dari penurunan berat terjadi pada rentang suhu $50-100{ }^{\circ} \mathrm{C}$ sebesar 37,55\% yang diperkirakan kehilangan air kristal (superficial) sebagai akibat dari senyawa bersifat higroskopis. Proses dekomposisi lanjutan, kompleks polimer menghasilkan puncak eksotermik pada suhu $269^{\circ} \mathrm{C}$ sebesar $4,75 \%$ yang menunjukkan hilangnya setengah mol DMF. Dalam tahap kedua ini terjadi dekomposisi lebih lanjut kompleks polimer anhidrat $\left\{\left[\mathrm{Ni}(\mathrm{NCS})_{2}(2,4,5 \text {-trifenil-1H-imidazol })_{2}\left(\mathrm{H}_{2} \mathrm{O}\right)_{2}\right] \mathrm{DMF}\right\} \mathrm{n}$. Ini ditunjukkan oleh penurunan berat yang sangat signifikan pada kisaran suhu $294-347^{\circ} \mathrm{C}$ sebesar $50,07 \%$ terjadi dekomposisi ligan 2,4,5-trifenil-1H-imidazol dan komponen organik. Kompleks polimer menghasilkan residu $\mathrm{NiO}$ pada suhu $500^{\circ} \mathrm{C}$ sebesar 7,63\%.

Analisis termogravimetri memiliki 3 pola penurunan berat. Tahap pertama menunjukan kehilangan pelarut dan/atau ligan organik; tahap kedua, degradasi ligan organik; dan tahap ketiga, degradasi lebih lanjut dari 


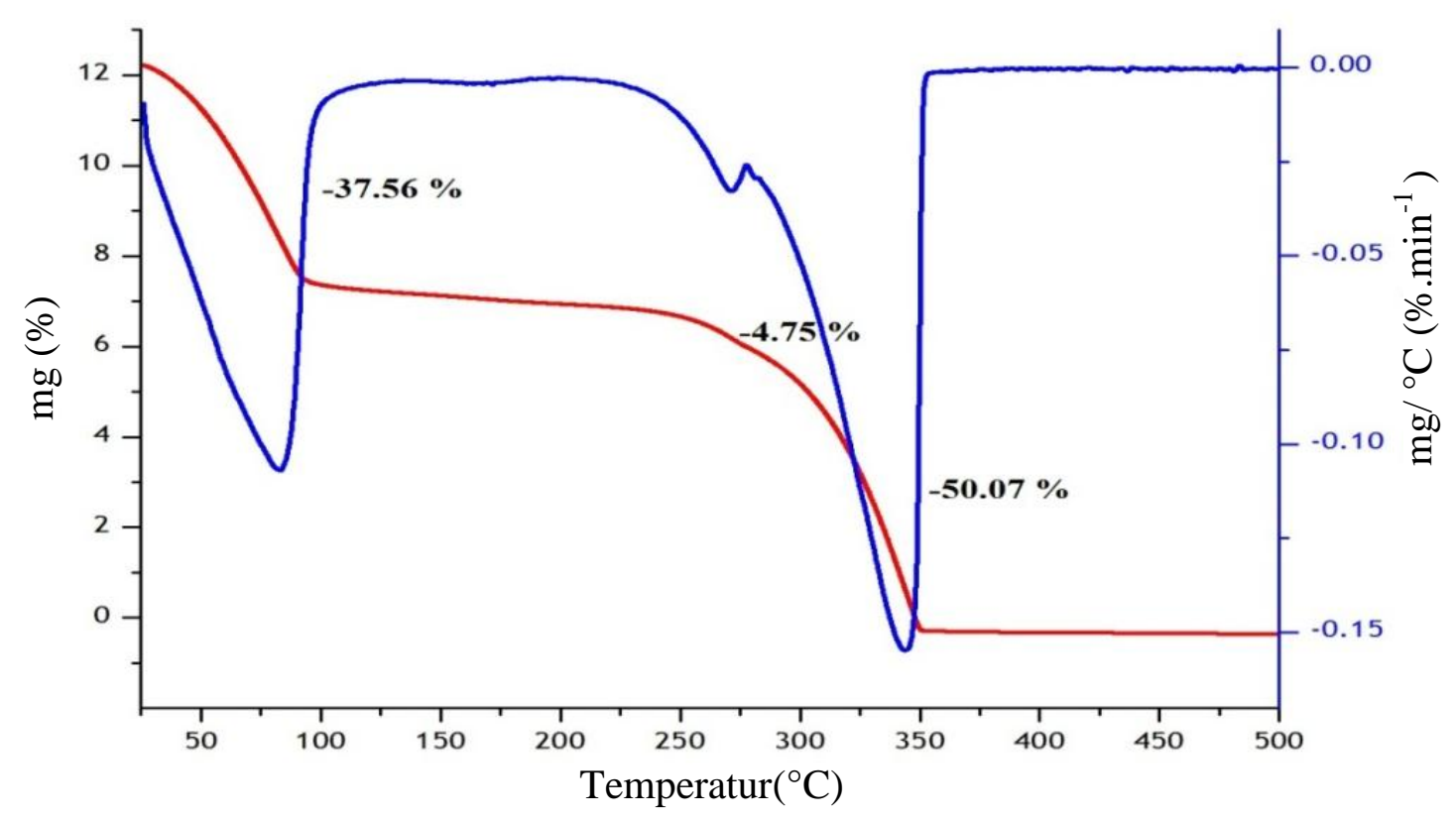

Gambar 3.4 Kurva DTA-TGA $\left\{\left[\mathrm{Ni}(\mathrm{NCS})_{2}(2,4,5 \text {-trifenil-1H-imidazol })_{2}\left(\mathrm{H}_{2} \mathrm{O}\right)_{2}\right] \bullet \mathrm{DMF}\right\}_{\mathrm{n}}$

ligan hingga menghasilkan residu $\mathrm{NiO}$ atau NIC. Pada kompleks polimer yang sama $\left[\mathrm{Ni}_{2}(\mathrm{~L})_{2}\left(\mathrm{NCS}_{2}\right] \mathrm{H}_{2} \mathrm{O}\right.$ (L: 6mercapto- (1,4,8,11-tetraazaundecanil) -6-karboksilat) oleh Dumbrava et al, (2014), melaporkan bahwa ada tiga fase dekomposisi yaitu (1) endotermik, pengurangan molekul air pada suhu $67-115{ }^{\circ} \mathrm{C}$; (2) degradasi ligan organik pada $115-380{ }^{\circ} \mathrm{C}$; (3) dekomposisi dari ligan organik dan tiosianat pada $380-626^{\circ} \mathrm{C}$, selanjutnya pada suhu $670{ }^{\circ} \mathrm{C}$ terjadi residu $\mathrm{NiO}$.

\subsection{Karakterisasi}

Scanning Electron Microscopy-Energy Dispersive X-ray (SEM-EDX)

Kompleks polimer $\left\{\left[\mathrm{Ni}(\mathrm{NCS})_{2}(2,4,5\right.\right.$-trifenil- $1 \mathrm{H}-$ imidazole $\left.\left.)_{2}(\mathrm{H} 2 \mathrm{O})_{2}\right] \cdot \mathrm{DMF}\right\} \mathrm{n}$ dikarakterisasi dengan scanning electron microscopy (SEM) yang sudah dilapisi Palladium (Pd) terlebih dahulu, dengan tegangan pemercepat $20 \mathrm{kV}$ dan perbesaran $1500 \mathrm{x}$. Working distance yang digunakan adalah $7,5 \mathrm{~mm}$, rata rata morfologi ukuran partikel diketahui sebesar $10 \mu \mathrm{m}$, dan ukuran partikel berkisar diantara 7-12 $\mu \mathrm{m}$. Gambar 3.5 menunjukkan tiap sisi kristal berfasa homogen.

\section{Kapasitas Adsorpsi Hidrogen}

Kemurnian kristal merupakan salah satu faktor untuk menentukan struktur dan kemampuan material sebagai penyimpan hidrogen. Hal ini berkaitan dengan jumlah dari adsorpsi total melalui proses fisisorpsi, khususnya untuk material yang mempunyai logam aktif. Material $\left\{\left[\mathrm{Ni}(\mathrm{NCS})_{2}(2,4,5\right.\right.$-trifenil- $1 \mathrm{H}-$ imidazol $\left.\left.)_{2}(\mathrm{H} 2 \mathrm{O})_{2}\right] \cdot \mathrm{DMF}\right\} \mathrm{n}$ diperoleh dalam bentuk polikristalin. Kristal tersebut memiliki pori sehingga molekul $\mathrm{H}_{2}$ dapat masuk ke dalam pori dan/atau pada permukaan material.

Logam transisi yang digunakan sebagai material penyimpan hidrogen mempengaruhi entalpi adsorpsi hidrogen. Ion logam yang dominan pada framework meningkatkan entalpi adsorpsi hidrogen [Ma Shenggian, 2009]. Transition metal that used for hydrogen storage material have an influence on hydrogen adsorption enthalpy. The dominance of metal ions in the framework increasing hydrogen adsorption enthalpy [Ma Shenggian, 2009]. Dari semua logam transisi pada periode pertama ( $\mathrm{Zn}, \mathrm{Co}, \mathrm{Mn}$, dan $\mathrm{Mg}$ ), ion $\mathrm{Ni}^{2+}$ memiliki radius paling kecil $(0,63 \AA)$ dan jarak $M-\mathrm{H}_{2}$ yang paling pendek $(2,00$ A) [Zhou, W., 2008], sehingga energi ikatan dari ion $\mathrm{Ni}^{2+}$ lebih tinggi daripada $\mathrm{Zn}$, Co, Mn, dan $\mathrm{Mg}$. Sebaliknya, peningkatan adsorpsi juga dipengaruhi oleh afinitas hidrogen.

Kapasitas adsoprsi total tidak hanya berasal dari kapasitas adsorpsi pada permukaan padatan tapi juga dipengaruhi oleh tekanan, oleh karena itu terdapat banyak gas hidrogen yang termampatkan di permukaan dan pori pada suhu ruang. Hal ini disebabkan oleh gaya van der Waals yang mendasari bahwa fisisorpsi relatif lemah. Oleh karena itu, kapasitas adsorpsi hidrogen dari material berpori menjadi kecil pada suhu ruang. 


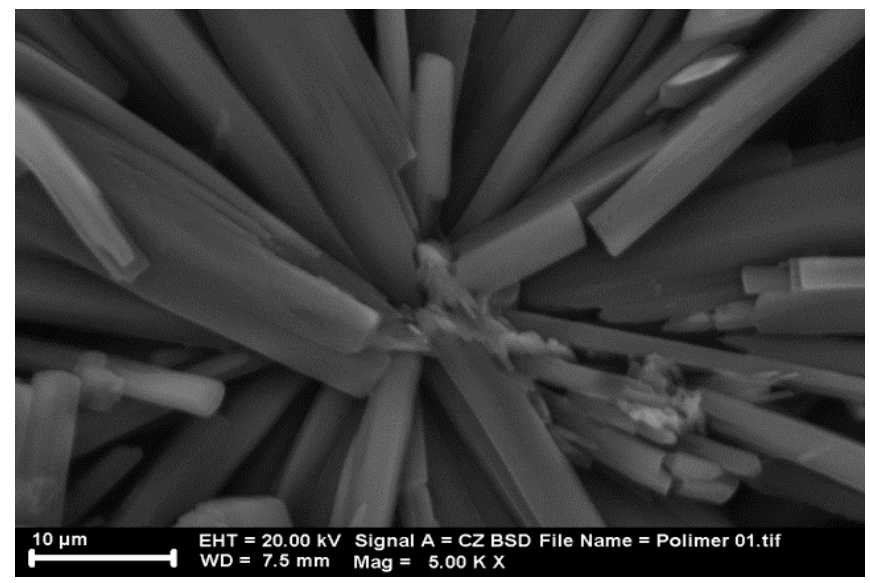

\section{Gambar 3.5 SEM characterization of complex polymer $\left\{\left[\mathrm{Ni}(\mathrm{NCS})_{2}(2,4,5 \text {-trifenil-1H-imidazol })_{2}\left(\mathrm{H}_{2} \mathrm{O}\right)_{2}\right]^{*}\right.$ DMF $\}_{\mathbf{n}}$}

Adsorpsi hidrogen pada $\left\{\left[\mathrm{Ni}(\mathrm{NCS})_{2}(2,4,5\right.\right.$-trifenil-1Himidazol $\left.\left.)_{2}\left(\mathrm{H}_{2} \mathrm{O}\right)_{2}\right] \cdot \mathrm{DMF}\right\}$ n ditentukan pada suhu $298 \mathrm{~K}$, tekanan 1 atm, selama 38 jam. Berdasarkan adsorpsi hidrogen (Gambar 3.6), adsorpsi konstan diperoleh setelah 28 menit. Hal ini mengindikasikan bahwa adsorben memerlukan waktu 28 menit untuk mengadsorb hidrogen secara optimal. Adsorpsi hidrogen optimal pada pori-pori tersebut tidak diperoleh pada suhu ruang, hal ini karena pergerakan yang cepat dari molekul $\mathrm{H}_{2}$ (diameter kinetik $\mathrm{H}_{2}$ sebesar 2,827-2,89 $\AA$ ). Kapasitas penyimpan hidrogen diperoleh sebesar $2,048 \%$ berat.

\section{Kesimpulan}

Kompleks polimer $\left\{\left[\mathrm{Ni}(\mathrm{NCS})_{2}(2,4,5\right.\right.$ triphenyl- $1 \mathrm{H}-$ imidazole $\left.\left.)_{2}\left(\mathrm{H}_{2} \mathrm{O}\right)_{2}\right] \cdot \mathrm{DMF}\right\}_{\mathrm{n}}$ telah berhasil disintesis dengan rasio molar $1: 4: 2$ menggunakan metode solvotermal. Adanya permukaan dan pori yang terbuka pada senyawa polimer dibuktikan oleh jumlah kapasitas adsorpsi hidrogen yang diperoleh dari metode gravimetri yaitu sebesar $2,048 \%$ berat. Berdasarkan hal tersebut, kompleks polimer $\left\{\left[\mathrm{Ni}(\mathrm{NCS})_{2}(2,4,5\right.\right.$-trifenil-1Himidazol $)_{2}\left(\mathrm{H}_{2} \mathrm{O}\right)_{2}$ ].DMF $\mathrm{n}$ mempunyai potensi untuk diaplikasikan sebagai material penyimpan hidrogen karena mampu untuk mengadsorb gas hidrogen dan sifatnya yang relatif stabil.

\section{Ucapan Terimakasih}

Penulis mengucapkan terimakasih pada Direktorat Pendidikan Tinggi, Menteri Pendidikan dan Kebudayaan Republik Indonesia atas dukungan penelitian unggulan tahun 2015.

\section{Daftar Pustaka}

[1] Bailey R. A., Kozak S. L., Michelsen T. W. and Mills W. N., (1971), Infrared spectra of complexes of the thiocyanate and related ions, Coord. Chem. Rev., 6, 407445.

[2] Brown, ME., (2001), Introduction to thermal analysis: techniques and application, 2nd edn., Kluwer Academic Publishers, New York.

[3] Clark R. J. S. and Williams C. S., (1966), Infra-red Spectra (3000-200 cm-1) of Metal-isothiocyanate Complexes, Spectrochim., Acta 22, 1081-1090.

[4] Dinca, M., Yu, Anta F., dan Long, Jeffrey R., (2006), Microporous Metal-Organic Frameworks Incorporating 1,4-Benzeneditetrazolate: Syntheses, Structures, and Hydrogen Storage Properties, J. Am. Chem. Soc., 128, 8904-8913.

[5] Hirscher, M., (2009), Handbook of Hydrogen Storage: New Materials for Future Energy Storage, WILEY-VCH Verlag GmbH \& Co. KGaA, Weinheim.

[6] Hoang, T.K.A., Antonelli, D.M., (2009), Exploiting the Kubas Interaction in the Design of Hydrogen Storage Materials, Adv. Mater., 21, 1787-1800.

[7] Jain I. P., (2009), Hydrogen The Fuel for 21st Century, International Journal of Hydrogen Energy, 34, 73687378.

[8] Karayannis, Nicholas M. dan Chester M. Mikulski, (1982), Lophine Complex with Nickel(II) Perchlorate, Inorganica Chimica Acta, 65, 1233-1234.

[9] Kaveh Mazloomi dan Chandima Gomes, (2012), Hydrogen as an Energy Carrier: Prospects and Challenges, Renewable and Sustainable Energy Reviews, 16, 3024-3033.

[10] Ma Shengqian, (2009), Gas Adsorption Applications of Porous Metal-organic frameworks, Pure Appl. Chem., 81, 2235.

[11] Marzouk, A., Vagif M. A., Avtandil H. T., dan Shaaban K. M., (2013), Synthesis of 2,4,5-Triphenyl Imidazole Derivatives Using Diethyl Ammonium Hydrogen 
Phosphate as Green, Fast and Reusable Catalist, World Journal of Organic Chemistry, Science and Education Publishing, Vol.1, No.1, 6-10.

[12] Myunghyun P. S., Hye J. P., Thazhe K. P., dan DaeWoon L., (2012), Hydrogen Storage in Metal-Organic Frameworks, Chem. Rev., 112, 782-835.

[13] Nakamoto, K., (1986), Infrared and Roman Spectra of Inorganic and Coordination Compounds, 4th ed., Wiley, New York.

[14] Nobakht, V., Beheshti, A., Proserpio, D. M., Carlucci, L. \& Abrahams, C. T., (2014), Influence of the Counter Anion and Steric Hindrance of Pyrazolyl and Imidazolyl Flexible Ligands on the Structure of Zinc-based Coordination Polymers, Inorganica Chim. Acta., 414, 217-225.

[15] Norbury A. H., (1975), Coordination Chemistry of the Cyanate, Thiocyanate, and Selenocyanate Ions, In Advances in Inorganic Chemistry and Radiochemistry (ed. H.J. Emeléus and A.G. Sharpe), Academic Press, pp. 231-386.

[16] Noro, Shin-ichiro., Susumu K., Tomoyuki A. dan Takayoshi N., (2009), Coordination Polymers Constructed from Transition Metal Ions and organic Ncontaining Heterocyclic Ligands: Crystal Structures and Microporous Properties, Progress in Polymer Science, 34, 240-279.

[17] Quan, Y.-P., Yin, P., Han, N.-N., Yang, A.-H., Gao, H.L., Cui, J.-Z., Shi, W., Cheng, P., (2009), Novel hetero- polynuclear metal complexes (CuL)3[Mn(NCS)5]2 and (NiL)3[Mn(NCS)5]2 containing trigonal bipyramidal geometric [Mn(NCS)5]3- as bridging ligand, Inorg. Chem. Commun., 12, 469-472.

[18] Thomas K.M., (2007), Hydrogen Adsorption and Storage on Porous Materials, Catalysis Today, 120, 389398.

[19] Wild, A., Teichler, A., von der Ehe, C., Winter, A., Hager, M.D., Yao, B., Zhang, B., Xie, Z., Wong, W.-Y., Schubert, U.S., (2013), ZnIIBisterpyridine Metallopolymers: Improved Processability by the Introduction of Polymeric Side Chains, Macromol. Chem. Phys., 214, 1072-1080.

[20] Wöhlert, S. \& Näther, C., (2013), New cobalt and nickel thiocyanato coordination polymers with pyridazine: Synthesis, structure and desolvation/resolvation behavior, Spec. ISSUE 100th Anniv. AWARD 1913 NOBEL PRIZE Chem. ALFRED WERNER Celebr., 52, 1073 1080.

[21] Xue, Gi., Dong, Jian., dan Sun, Yueming., (1994), Complex-Induced Activating Effect on Surface Species: Reactions of Imidazole on Zero Oxidation State Metal Surfaces, Langmuir, 10, 1477-1481.

[22] Zhou, Wei., Hui Wu, dan Taner Yildirim, (2008), Enhanced H2 Adsorption in Isostructural Metal-Organic Frameworks with Open Metal Sites: Strong Dependence of the Binding Strength on Metal Ions, J. Am. Chem. Soc., 130, 15268-15269. 